LUMINOL-ENHANCED chemiluminescence was measured in fresh whole human blood, or human neutrophils isolated from heparinized blood, human alveolar macrophages and rat alveolar macrophages stimulated with bacterial endotoxin (LPS). Tetraacetate esters of rooperol, a dicatechol showing anticytokine activity, added to cells simultaneously with LPS inhibited the respiratory burst. The effective concentrations of rooperol were in the range of $1-10 \mu \mathrm{M}$ depending on cell type and corresponded well with inhibition of nitric oxide production by rat alveolar macrophages. Thus rooperol may reduce some effects of excessive phagocytic activity and inflammatory reaction but by quenching free radicals production may also diminish the resistance to bacterial infections.

Key words: Chemiluminescence, Endotoxin, Nitric oxide production, Phagocytes, Respiratory burst

\section{Rooperol, an inhibitor of cytokine synthesis, decreases the respiratory burst in human and rat leukocytes and macrophages}

\author{
A. Guzdek, ${ }^{1}$ B. Turyna, ${ }^{1}$ A. C. Allison, ${ }^{2}$ K. Stadek ${ }^{3}$ \\ and $A$. Koj ${ }^{1, C A}$
}

${ }^{1}$ Institute of Molecular Biology, Jagiellonian University, 31-120 Cracow, Poland; ${ }^{2}$ DAWA Inc., Belmont, CA 94002, USA; ${ }^{3}$ Institute of Internal Medicine, Collegium Medicum, Jagiellonian University, 31-066 Cracow, Poland

${ }^{\mathrm{CA}}$ Corresponding Author

Fax: $(+48) 12336907$

\section{Introduction}

Phagocytes from blood, i.e. polymorphonuclear leukocytes and monocytes, and tissue macrophages, are involved in complex defence mechanisms against pathogenic bacteria. During phagocytosis they exhibit increased metabolic activity known as respiratory burst which generates superoxide as its primary product. Superoxide is formed in effect of oxygen reduction by NADPHoxidase, a multicomponent enzyme present in the cell membrane of phagocytes. ${ }^{1}$ In a series of further reactions, superoxide gives rise to reactive oxygen intermediates (ROI) such as hydrogen peroxide, hydroxyl radical and hypochlorous acid which serve as microbicidal agents but produced in excess may damage host cells. ${ }^{2}$ Respiratory burst is induced not only by intact bacteria but also by opsonized particles, endotoxin, some cytokines (tumour necrosis factor, $\mathrm{TNF} \alpha$, interferon- $\gamma$, IFN- $\gamma$ ), N-formylated chemoattractant peptides and activators of kinase $\mathrm{C}$ (phorbol esters). ${ }^{1}$ Bactericidal activity is also generated by reactive nitrogen intermediates, such as nitric oxide $(\mathrm{NO})^{3}$ possessing a broad spectrum of biological activities and produced in macrophages by inducible nitric oxide synthase (iNOS). ${ }^{4}$ The interaction between reactive oxygen and nitrogen intermediates leads to peroxynitrite and may increase cytotoxicity or inflammation. ${ }^{3}$ Thus it is not surprising that simultaneous inhibition of nitric oxide synthase and NADPH oxidase suppress inflammatory arthritis. ${ }^{5}$ Moreover, some antioxidants show anti-inflammatory properties and inhibit synthesis of acute phase cytokines. ${ }^{6,7} \mathrm{We}$ recently demonstrated that rooperol, a plant dicatechol, decreases production of tumour necrosis factor (TNF $\alpha$ ), interleukin-1 (IL-1) and interleukin-6 (IL-6) in LPS-stimulated human and rat macrophages and $\mathrm{NO}$ production in rat macrophages. ${ }^{78}$ Here we describe the effect of rooperol tetraacetate on the respiratory burst in human and rat phagocytes.

\section{Materials and Methods}

\section{Reagents}

Mono-Poly resolving medium was obtained from ICN Biomedicals, Meckenheim, Germany. RPMI and antibiotics-antimycotics came from Gibco Life Technologies Inc., Grand Island, NY, USA. Fetal bovine serum (FBS), lipopolysaccharide from Escherichia coli 026:B6 (LPS), luminol (5amino-2,3-dihydro-1,4-phthalazinedione), latex beads $(1 \mu \mathrm{m})$, glucose were purchased from Sigma, St Louis, MO, USA. Rooperol tetraacetate (RTA) was kindly provided by Dr P. B. Kruger, ESP Group, Department of Pharmacology, Uni- 
versity of Stellenbosch, South Africa. All other reagents obtained from $\mathrm{POCH}$, Gliwice, Poland were of highest purity grade.

\section{Cells, isolation and culture}

Twenty $\mu$ of whole bood was taken from the finger of healthy volunteers (25-48 years of age) and used immediately for respiratory burst measurement. Neutrophils were isolated from fresh heparinized human blood of healthy donors by centrifugation with Mono-Poly resolving medium, washed in Hanks' Balanced Salt Solution (HBSS) without $\mathrm{Ca}^{2+}$ and c. 5000 cells were used for experiments. Human lung macrophages were obtained by fibre-optic bronchoscopy of patients examined for diagnostic purposes following the guidelines of the American Thoracic Society. The cells were collected in sterile phosphate buffered saline (PBS), centrifuged, washed in PBS and c. 5000 cells were used for each experiment. The lungs of killed by ether overdose rats were lavaged with $3 \times 10 \mathrm{ml}$ of cold PBS. After centrifugation, the cell pellet was washed in cold PBS and $2 \times 10^{4}$ cells were used for respiratory burst estimation.

$\mathrm{NO}$ production by rat alveolar macrophages was evaluated in $24 \mathrm{~h}$ culture of the cells. Isolated rat macrophages were seeded on 12 well plates (Costar) in RPMI with $8 \%$ fetal bovine serum and antibiotics. After $2 \mathrm{~h}$ the unattached cells were discarded, and the adherent cells were cultured for $24 \mathrm{~h}$. Then rooperol tetraacetate (RTA) and/or LPS (500 ng/ml) in RPMI containing 2\% FBS was added. NO was estimated in the medium collected after $24 \mathrm{~h}$ culturing the cells with the drugs.

\section{Estimation of chemiluminescence (CL) and NO production}

Whole blood in HBSS containing glucose and $0.5 \%$ FCS was incubated for 10 min with luminol $(1.4 \mathrm{mM})$, RTA $(0.6,2,5$ and $10 \mu \mathrm{M})$ and/or $10 \mathrm{ng} / \mathrm{ml}$ LPS. The addition of $50 \mu \mathrm{l}$ of latex beads $\left(2 \times 10^{10}\right)$ was the start point of chemiluminescence estimation in Scintillation Spectrometer Rackbeta 1211, LKB. ${ }^{10}$ Neutrophils and macrophages were incubated with luminol, RTA and/or LPS for $20 \mathrm{~min}$. As a result of exposure to latex beads respiratory burst occurs and its intensity depends on phagocytes priming by LPS.

NO production was estimated with Griess reagent and nitrite concentration was determined by using dilutions of sodium nitrite in water as a standard. ${ }^{11}$ Rooperol tetraacetate at
$20 \mu \mathrm{M}$ concentration had no effect on nitrite assay.

\section{Statistical analysis}

Data were analysed by paired Student's $t$ test.

\section{Results}

\section{Effect of rooperol on the respiratory burst of human cells}

Addition of bacterial endotoxin $(10 \mathrm{ng} / \mathrm{ml})$ to fresh human blood or isolated neutrophils followed by latex beads increased chemiluminescence within the first 15-20 min (Table 1) and a decline occurred usually around 3040 min after the addition of latex beads. However, considerable individual variations were observed, especially with full blood, in which the maximum was often delayed or prolonged (Fig. 1). When rooperol tetracetate was added to fresh human blood simultaneously with LPS a marked reduction of respiratory burst was found (Fig. 1a and 1ax) and occasionally the chemiluminescence was reduced below control (Fig. 1ax). Similar inhibitory effects of rooperol were also visible with neutrophils isolated from human peripheral blood (Fig. 1b) and human alveolar macrophages (Fig. 1c). These effects were dose-dependent and for human neutrophils and macrophages almost total inhibition of respiratory burst occurred at $10 \mu \mathrm{M}$ RTA (Fig. $1 \mathrm{~b}$ and $1 \mathrm{c}$ ). In the case of full blood or isolated neutrophils $10 \mu \mathrm{M}$ RTA reduced latex-beadsinduced chemiluminescence by approximately three-fold (Fig. 2). A similar inhibition of chemiluminescence was observed in one experiment with isolated human blood monocytes (data not shown).

Table 1. Stimulatory effect of LPS $(10 \mathrm{ng} / \mathrm{ml})$ on latexbeads-induced chemiluminescence of cells present in $20 \mu \mathrm{l}$ of fresh human blood or isolated neutrophils ( $\sim 5000$ cells). The chemiluminescence was recorded after 3, 9, 15 and $21 \mathrm{~min}$ following the addition of latex beads. The results are reported as percentage of control preparation (without LPS) assumed as $100 \%$ at any given time in each experiment: mean \pm SD of between three and eight independent experiments. Statistically significant differences at ${ }^{*} P<0.05$, ${ }^{* *} P<0.01,+P<0.005$ and $++P<0.002$. NS, not significant

\begin{tabular}{lcccc}
\hline Cells & \multicolumn{4}{c}{ Time (min) } \\
\cline { 2 - 5 } & 3 & 9 & 15 & 21 \\
\hline $\begin{array}{l}\text { Full } \\
\text { blood }\end{array}$ & $132 \pm 43^{* *}$ & $163 \pm 45^{+}$ & $191 \pm 41^{+}$ & $242 \pm 92^{*}$ \\
$\begin{array}{l}\text { Neutro- } \\
\text { phils }\end{array}$ & $128 \pm 28$ (NS) & $176.29^{*}$ & $191.16^{+}$ & $161 \pm 27^{++}$ \\
\hline
\end{tabular}



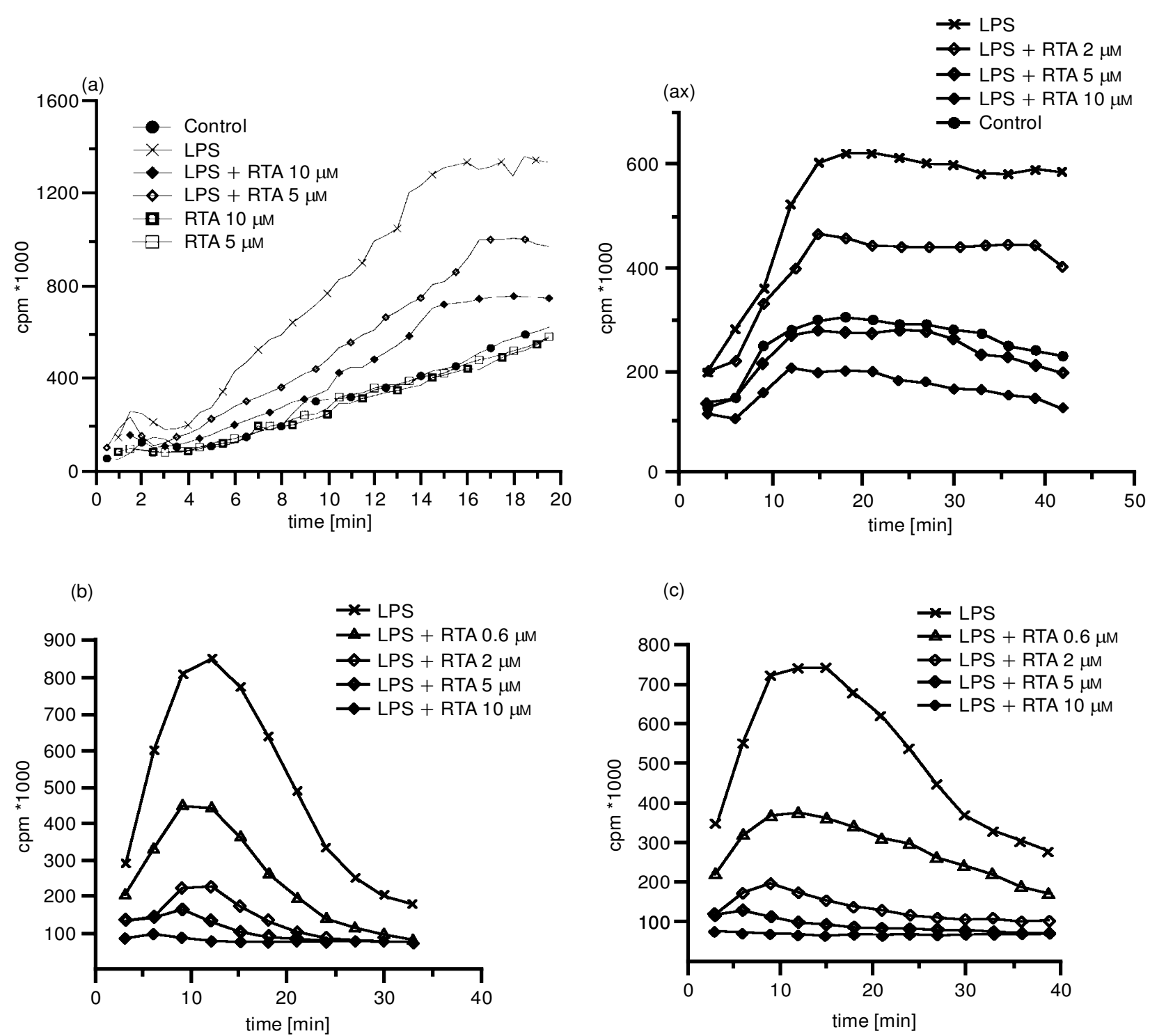

FIG. 1. The inhibitory effect of RTA $(0.6,2,5$ and $10 \mu \mathrm{M})$ on chemiluminescence induced by LPS (10 $\mathrm{ng} / \mathrm{ml})$ and latex beads suspension $(50 \mu \mathrm{l})$ in white cells present in $20 \mu \mathrm{l}$ of full human blood (a and ax); in 5000 neutrophils isolated from peripheral human blood (b); or in 5000 human alveolar macrophages (c). Fresh full blood was preincubated with luminol, RTA and/or LPS for $10 \mathrm{~min}$, isolated neutrophils and macrophages for $20 \mathrm{~min}$, and then latex beads were added and chemiluminescence measured.

Effect of rooperol on the respiratory burst and NO production by rat macrophages

The respiratory burst of rat alveolar macrophages primed with LPS was also quenched by rooperol (Fig. 3). In the conditions used, rat alveolar macrophages response to RTA was less pronounced in comparison with human macrophages. Moreover, the maximal response to 10 $\mathrm{ng} / \mathrm{ml}$ of LPS occurred faster (in about $5 \mathrm{~min}$ after phagocytosis initiation) but also declined earlier (Fig. 3). When rat alveolar macrophages were cultured for $24 \mathrm{~h}$ with $500 \mathrm{ng} / \mathrm{ml}$ of LPS they produced significant amounts of nitric oxide determined as nitrite $(123.8 \pm 17.8 \mathrm{nmol} /$ $\mathrm{ml}, n=6)$. Rooperol reduced $\mathrm{NO}$ production in a dose-dependent manner (Fig. 4), the $\mathrm{IC}_{50}$ was found to be between 5 and $10 \mu \mathrm{M}$.

\section{Discussion}

Acetate esters of rooperol, a dicatechol from the South African plant Hypoxis rooperi, were shown to inhibit production of TNFo, IL-1 $\beta$ and IL- 6 in endotoxin-stimulated human alveolar macrophages, blood monocytes and U937 promonocytic cell line? Rooperol tetraacetate (RTA) was effective in low micromolar range $\left(\mathrm{IC}_{50}=10-20 \mu \mathrm{M}\right)$ and at this concentration had no effect on cell viability as shown by the incorporation of ${ }^{14}$ Cleucine into macro- 


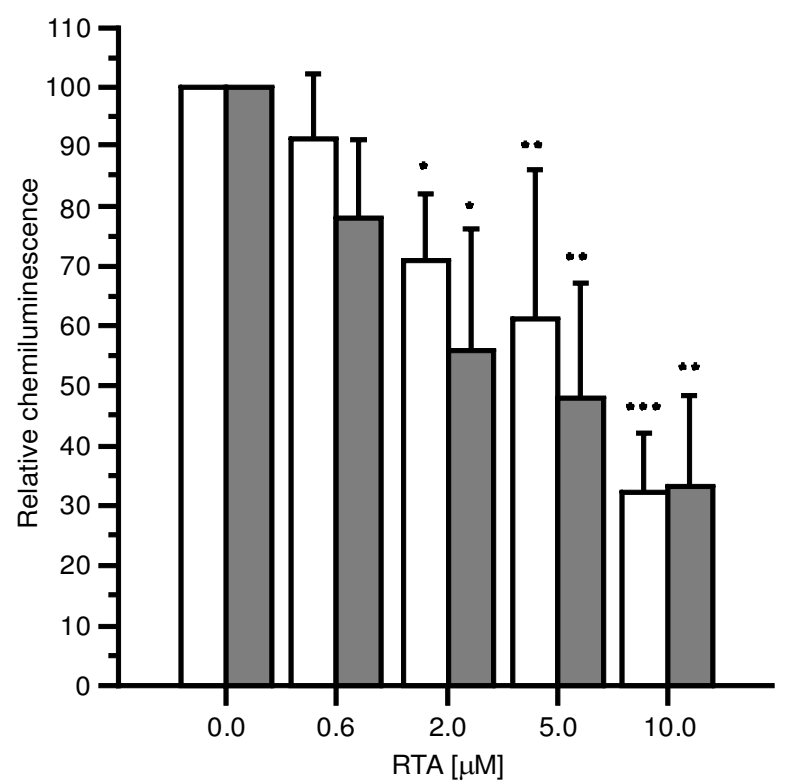

FIG. 2. Dose-dependent inhibition of LPS-stimulated chemiluminescence of cells from $20 \mu$ l of whole blood (empty bar) and neutrophils (5000 cells) (striped bar), $9 \mathrm{~min}$ after latex addition. Full blood was preincubated for $10 \mathrm{~min}$, neutrophils for 20 min with luminol, RTA and/or LPS. Chemiluminescence caused by LPS alone was assumed as $100 \%$. Mean $( \pm \mathrm{SD})$ of three to six experiments. Statistically significant differences at ${ }^{*} P<0.05,{ }^{* *} P<0.02$ and ${ }^{* * *} P<0.01$.

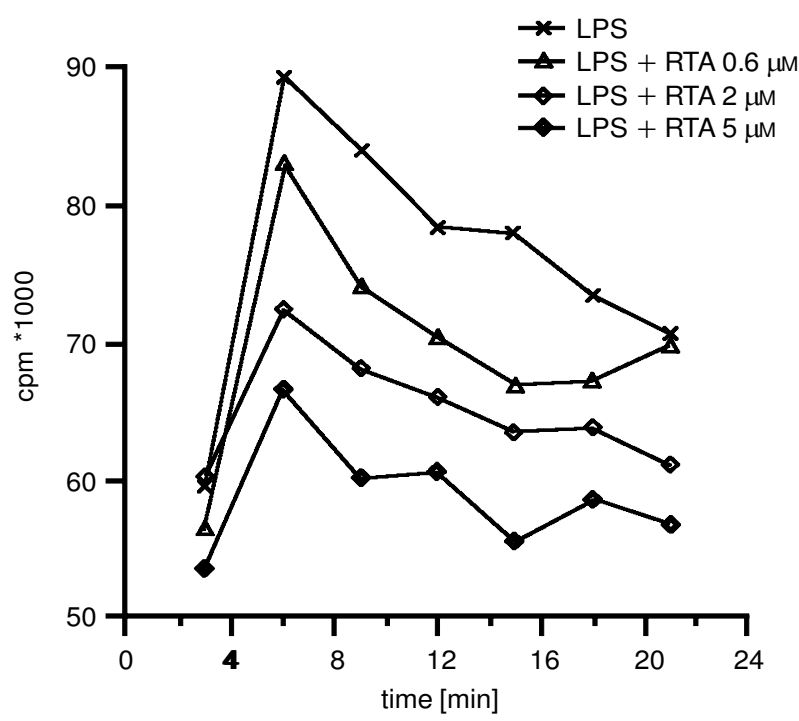

FIG. 3. Effect of RTA (1, 2.5 and $5 \mu \mathrm{M})$ on chemiluminescence of $2 \times 10^{4}$ rat alveolar macrophages stimulated with $10 \mathrm{ng} / \mathrm{ml}$ LPS. For further explanations see legend to Fig. 1.

phage proteins and cellular contents of lactate dehydrogenase. Subsequent studies revealed that RTA may inhibit cytokine synthesis in promonocytic U937 cell line at the pretranslational level. ${ }^{8}$ All those results suggested that rooperol esters are potential anti-inflammatory drugs.

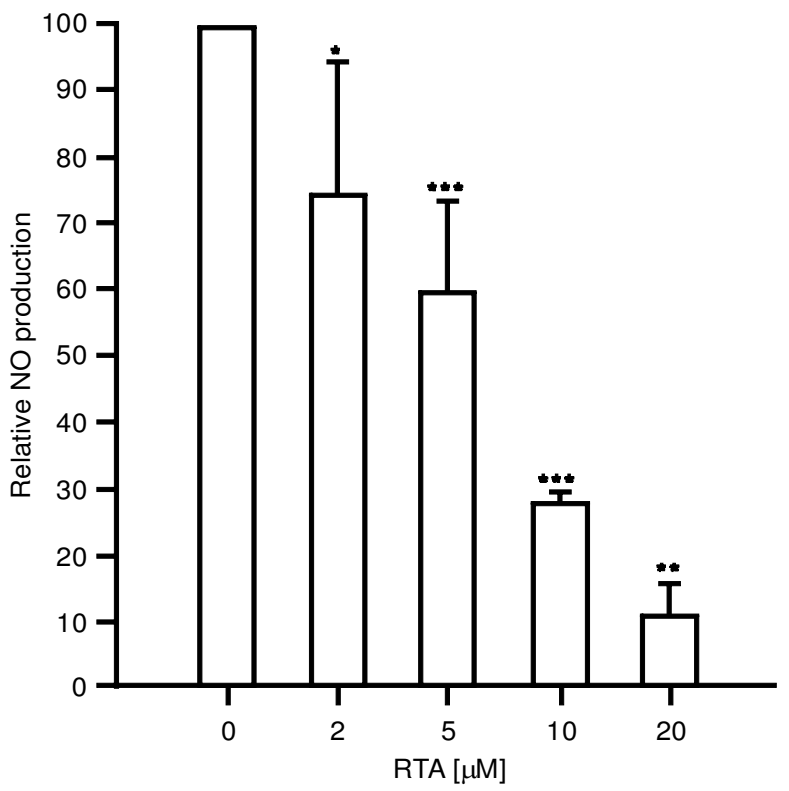

FIG. 4. Percentage inhibition of LPS-stimulated $(500 \mathrm{ng} / \mathrm{ml})$ $\mathrm{NO}$ production by rat alveolar macrophages cultured for $24 \mathrm{~h}$ with increasing concentrations of RTA. Mean ( \pm SD) of five to seven experiments. Statistically significant differences at ${ }^{*} P<0.05,{ }^{* *} P<0.005$ and ${ }^{* * *} P<0.001$.

The experiments described here clearly demonstrate another anti-inflammatory activity of rooperol, i.e. inhibition of the respiratory burst. We found that RTA at micromolar concentrations significantly decreased chemiluminescence of human blood leukocytes and alveolar macrophages, as well as of rat alveolar macrophages, that had been primed with LPS and stimulated to phagocytosis by latex beads. The mechanism of respiratory burst inhibition by rooperol is not elucidated but may involve events related to LPS priming, ${ }^{12}$ direct interaction with enzymatic pathway of oxygen radicals formed by NADP oxidase, ${ }^{1}$ or involvement of cell membrane constitutents including protein kinase $\mathrm{C}$ as described for coenzyme $\mathrm{Q}^{13}$ which is structurally related to rooperol.

Our results confirm earlier observations that RTA can also inhibit $\mathrm{NO}$ production in rat alveolar macrophages ${ }^{7}$ and murine endothelial cells. ${ }^{14}$ The broad spectrum of biological activities of rooperol suggests that this compound may be beneficial in the treatment of various inflammatory diseases, such as asthma or rheumatoid arthritis, in which overproduction of acute phase cytokines, nitric oxide and reactive oxygen intermediates has been reported. ${ }^{5,15} \mathrm{It}$ should be remembered, however, that by quenching free radicals production rooperol may also diminish the resistance of organism to bacterial infections. ${ }^{16}$ 


\section{References}

1. Maly FE, Schurer-Maly CC. How and why cells make superoxide: the 'phagocytic' NADPH oxidase. News Physiol Sci 1995; 10: 233-238.

2. Schreck R, Albermann K, Bauerle PA. Nuclear factor $\mathbf{\kappa B}$ : an oxidative stress-responsive transcription factor of eukaryotic cells. Free Rad Res Commun 1992; 17: 221-237.

3. Kaplan SS, Lancaster JR Jr, Basford RE, Simmons RL. Effect of nitric oxide on staphyloccocal killing and interactive effect with superoxide. Infect Im mun 1996; 64: 69-76.

4. Kroncke KD, Fehsel K, Kolb-Bachofen V. Inducible nitric oxide synthase and its product nitric oxide, a small molecule with complex biological activities. Biol Chem Hoppe-Seyler 1995; 376: 327-343.

5. Miesel R, Kurpisz M, Kroeger H. Suppression of inflammatory arthritis by simultaneous inhibition of nitric oxide synthase and NADPH oxidase. Free Radic al Biol Med 1996; 20: 75-81.

6. Eugui EM, DeLustro B, Rohafza S, Ilnicka M, Lee SW, Wilhelm R, Allison AC. Some antioxidants inhibit, in a co-ordinate fashion, the production of tumor necrosis factor- $\alpha$, IL-1 $\beta$, and IL- 6 by human peripheral blood mononuclear cells. Int Im mun 1994; 6: 409-422.

7. Guzdek A, Niżankowska E, Allison AC, Kruger PB, Koj A. Cytokine production in human and rat macrophages and dicatechol rooperol and esters. Biochem Pharm acol 1996; 52: 991-998.

8. Guzdek A, Rokita H, Cichy J, Allison AC, Koj A. Rooperol te traacetate, inhibitor of cytokine synthesis, decreases TNF $\alpha$, IL-1 $\beta$ and IL- 6 mRNA levels and binding activity of transcription factors in U937 cells. Biochem Pharm acol (submitted).

9. American Thoracic Society Guidelines. Summary and recommendation of a workshop on the investigational use of fiberoptic bronchoscopy and bronchoalveolar lavage in asthmatics. Am Rev Resp Dis 1985; 132: $180-182$.
10. Turyna B, Milc J, Łaczka A, Cholewa K, Łaczka M Biocompatibility of glass-crystalline materials obtained by the sol-gel method: effect on macrophage function. Biom aterials 1996; 17: 1379-1386.

11. Ding AH, Nathan CF, Stuehr DJ. Release of reactive nitrogen intermediates and reactive oxygen intermediates from mouse peritoneal macrophages: comparison of activating cytokines and evidence for independent production. J Immunol 1988; 141: 2407-2410.

12. Landmann R, Scherer F, Schumann R, Link S, Sansano S, Zimmerli W. LPS directly induces oxygen radical production in human monocytes via LPS binding protein and CD14. J Leukocyte Biol 1995; 57: $440-449$.

13. Kanno T, Utsumi T, Takehara Y, Ide A, Akiyama J, Yoshioka T, Horton AA, Ustumi K. Inhibition of neutrophil superoxide generation by alphatocopherol and coenzyme Q. Free Radical Res 1996; 24: 281-289.

14. Bereta J, Bereta M, Allison AC, Kruger PB, Koj A. Inhibitory effect of dicatechol rooperol on VCAM-1 and iNOS expression in cytokinestimulated epithelium. Life Sci 1997; 60: 325-334.

15. Barnes PJ, Liew FY. Nitric oxide and asthmatic inflammation. Im munol To day 1995; 16: $128-130$.

16. Evans TJ, Buttery LDK, Carpenter A, Springall DR, Polak JM, Cohen J. Cytokine-treated human neutrophils contain inducible nitric oxide synthase that produces nitration of ingested bacteria. Proc Natl Acad Sci USA 1996; 93: 9553-9558.

ACKNOWLEDGEMENTS. This work was supported in part by grant no. $1227 /$ P05/95/08 to A.K. from the Committtee of Scientific Research (KBN, Warsaw, Poland).

Received 24 October 1996;
accepted in revised form 27 November 1996 


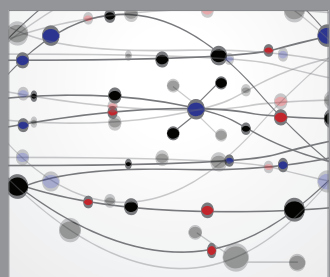

The Scientific World Journal
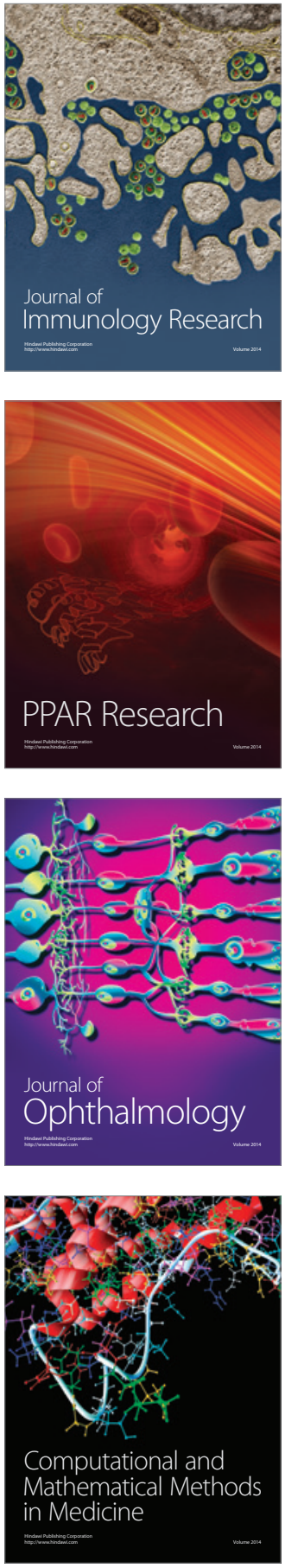

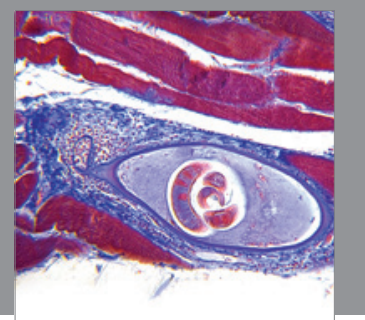

Gastroenterology

Research and Practice
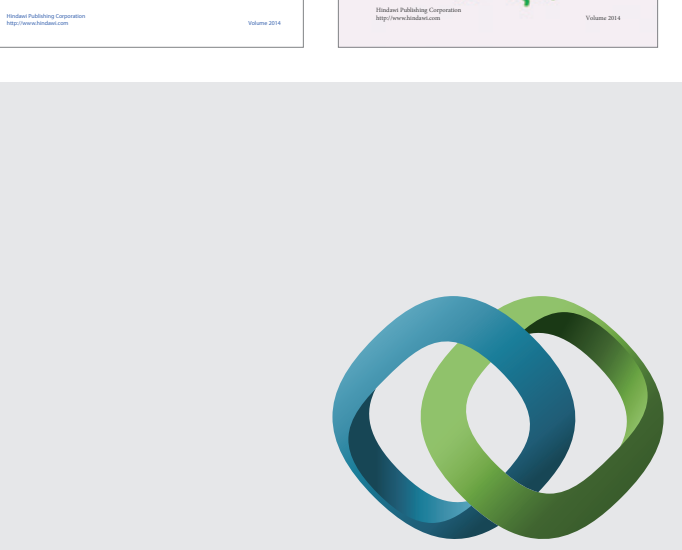

\section{Hindawi}

Submit your manuscripts at

http://www.hindawi.com
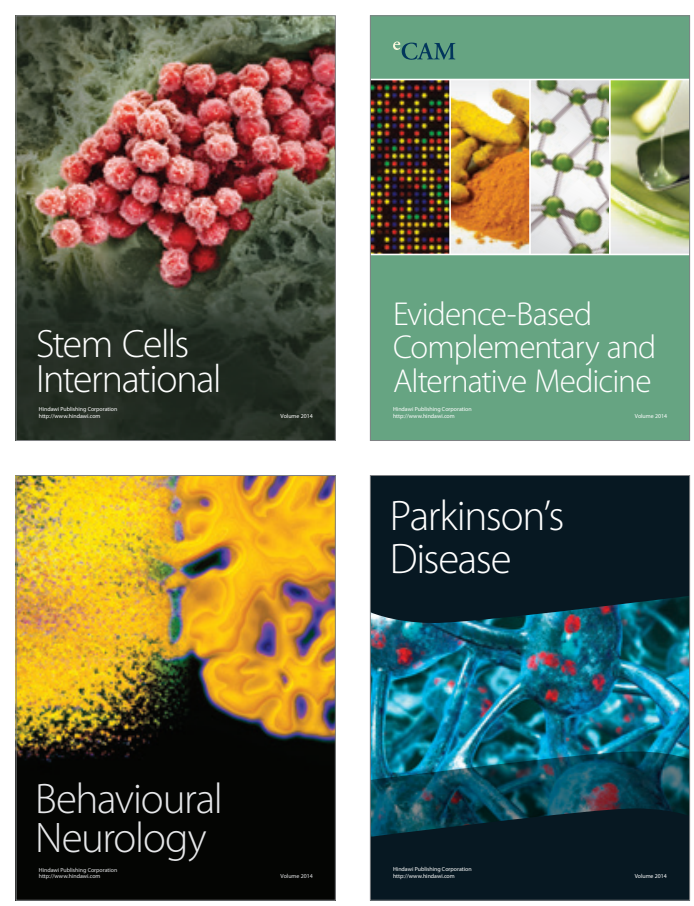

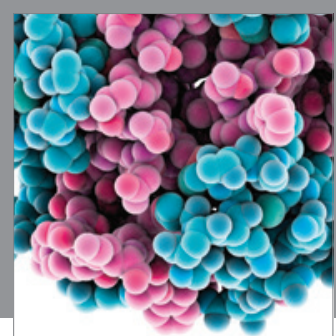

Journal of
Diabetes Research

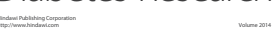

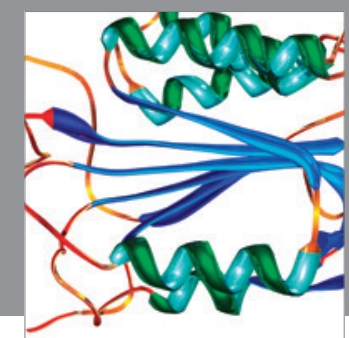

Disease Markers
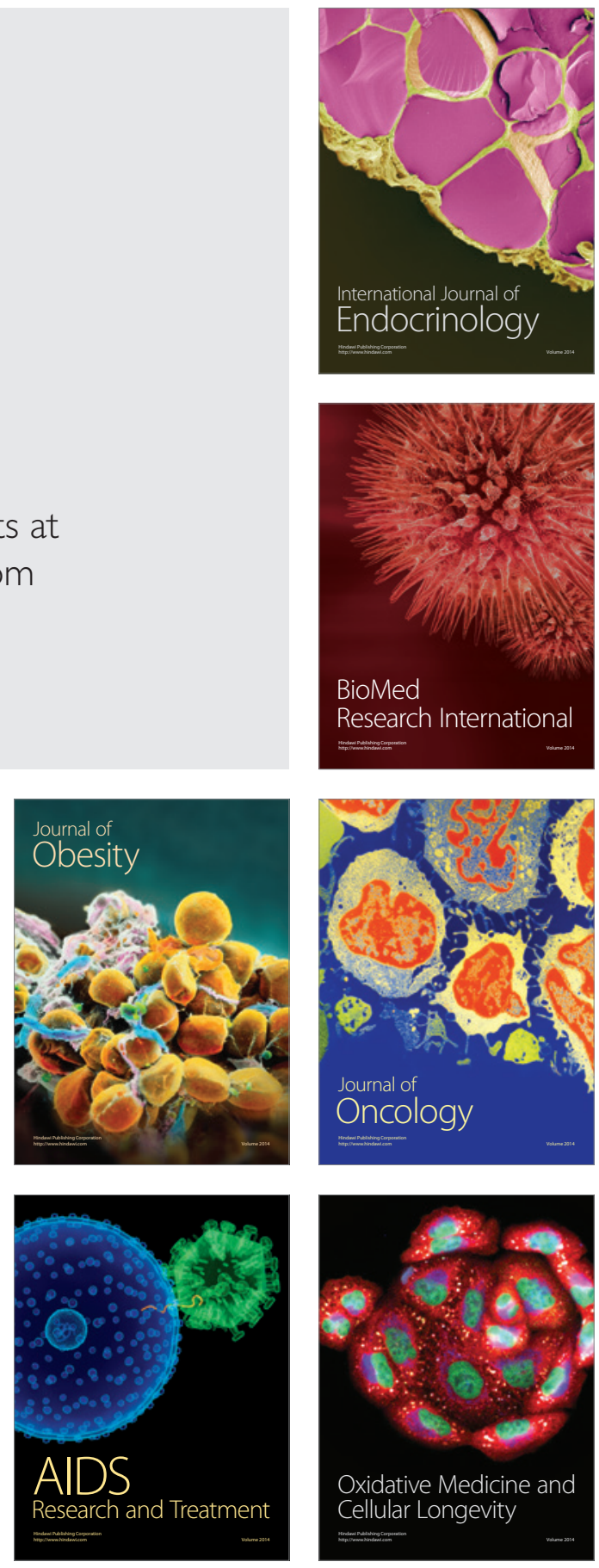